\section{International Scientific Journal Theoretical \& Applied Science}

Suhrob Dustmurodovich Norkulov

$\mathrm{PhD}$,

Senior scientific employee,

The National University of Uzbekistan conference_2012@list.ru

Year: $2015 \quad$ Issue: $07 \quad$ Volume: 27

Published: $30.07 .2015 \quad$ http://T-Science.org

SECTION 30. Philosophy.

\title{
SOME ASPECTS OF THE INTERRELATION OF THE SOCIAL CONSCIOUSNESS AND SPIRITUAL DEVELOPING OF SOCIETY
}

\begin{abstract}
In this article some of the main aspects that characterized the relationship of social consciousness and the development of the spiritual sphere of the society are considered. Today, the spiritual component of society is an essential component of sustainable development of any state, along with a material component. This problem is viewed through the prism of dialectical interaction, methodological principles, which can be diagnosed errors in the formation of the social consciousness in the past, their elimination and the prospect in the future.

Key words: social consciousness, person, individual consciousness, spiritual life of society, law, politics, morality, ideology, spiritual production, spiritual activity, material production, spiritual and material values.

Language: English

Citation: Norkulov SD (2015) SOME ASPECTS OF THE INTERRELATION OF THE SOCIAL CONSCIOUSNESS AND SPIRITUAL DEVELOPING OF SOCIETY. ISJ Theoretical \& Applied Science 07 (27): 104-106.
\end{abstract}

Soi: http://s-0-i.org/1.1/TAS-07-27-17 Doi: crossef http://dx.doi.org/10.15863/TAS.2015.07.27.17

The analysis of the spiritual life of society is one of the problems of social philosophy, the subject of which is not yet separated finally and definitely. Only recently some efforts were made to provide an objective characteristic of the spiritual sphere of the society. Famous Russian philosopher N.A.Berdyaev this situation was explained as follows: "In the realm of the Bolshevik revolution and its creation more than destruction, I soon realized the danger to the spiritual culture. The revolution did not spare the creators of spiritual culture, have been suspicious and hostile to spiritual values. Interestingly, when you had to register the all-Russian Union of writers, was not such a division of labour, which could be attributed to the work of the writer. The Writers' Union was registered in the category printing workers... Worldview, under symbols which proceeded the revolution, not only did not recognize the existence of spirit and spiritual activity, but also considered the spirit as an obstacle to the implementation of the Communist system, as counterrevolution" [1].

So for nearly three quarters of a century philosophy of the CIS countries was forced to deal with the problems of the Communist ideology, culture of socialism, etc. and have not studied the problems of the real spiritual processes going on in society [8].
What are the social consciousness and spiritual life of society?

One of the merit of K.Marx is the allocation of the "being in general" the social being, and of the "consciousness in general" the social consciousness - one of the basic concepts of philosophy. The objective world, influencing the person, is reflected in his views, thoughts, ideas, theories, and other spiritual phenomena, which form the social consciousness.

The structure of the social consciousness is very complex: first of all, it emits such levels as ordinarypractical and theoretical. This aspect of consideration of social consciousness can be called epistemological, as it shows the depth of penetration of a subject of cognition of objective reality. As we know, the routine of practical consciousness is less structured, more superficial than scientific theory. The social consciousness on the ordinary-practical level manifests itself as social psychology, on the scientific-theoretical level - as an ideology. It should be emphasized that the ideology is not all scientifictheoretical consciousness, but only that part which is of class character. But this will be discussed below.

The next aspect to consider of the social consciousness by its carrier or entity. Thus may be distinguished types of social consciousness individual, group and mass consciousness. A native 
of individual consciousness is an individual, the bearer of group consciousness - a social group, the media of mass consciousness the disorganized group of people united by some idea or concept, purpose. For example, to the phenomenon of mass consciousness can be attributed the fans of any pop singer, admirers of any newspapers, regular listeners of the radio station. It is sometimes said that the media of mass consciousness is the crowd, but many sociologists believe that it is more correct to highlight the consciousness of the crowd, and the consciousness of the masses. In passing, we note that the crowd is people in direct contact with each other, meeting for any purpose, but from the mass the crowd is distinguished by direct contact, the presence of a leader and work together, for example, at a rally, demonstration, etc.

The social consciousness is a combination of various spiritual phenomena, reflecting all aspects of society and the richness of individual human life, are so many forms - moral, aesthetic, religious, legal, political, philosophical, scientific, environmental, economic, etc. Of course, such a structuring is conditional, as the types, forms and levels of social consciousness are in constant interaction and mutual influence.

Analyzing of the social consciousness, social philosophy pays special attention to ideology. Ideology is a system of ideas and theories, values and norms, ideals and directives of the action. It contributes to the consolidation or elimination of existing social relations [5]. On the theoretical content of the ideology is a set of legal, political, moral, aesthetic and other ideas, reflecting ultimately the economic relations of society from the standpoint of a definite social class.

Let's focus on the spiritual life of society. Under it we can see the sphere of existence in which an objective, supra-individual reality has transformed into the reality of individual, subjective, inherent in every person.

The tradition of studying "the spirit" was founded by Plato, and who by this the philosophy understood as a doctrine about ideas. An ideal start becoming in Plato, primary, and material - an imperfect image of the ideal. The modern philosophy, though is based on many findings of Plato, has leaped forward [2]:

- what is the structure of the spiritual life of society;

- what are the main aspects of spirituality;

- what is the spiritual production.

The spiritual life of mankind is under the influence of material and economic life, so its structure can be represented in a similar way. The spiritual life includes: spiritual need, spiritual interest, spiritual activity and spiritual goods. The spiritual activity begets spiritual relationships moral, aesthetic, religious, political, legal, etc.
There we highlight the main aspects of spirituality:

1. The comprehensive nature of spirituality. Human spiritual life is multifaceted. It includes both the rational and the emotional-affective side, in gnoseological-cognitive and value-motivational moments, lucid and dimly perceived a face, focused on the external and internal world of an individual installation, as well as many other aspects, levels, condition of the spiritual life of the individual. The spirituality incorporates all these facets of human life.

2. The spirituality as ideality. Ideality in general, is characterized in that the content of any phenomena of the world interiorized (assigned) by the person in its pure form, freed from objective, material, subject, or spatial-temporal characteristics of existence. A huge role in the formation and development of ideality plays the language, categorical-conceptual system of human consciousness. The human spirituality is a perfect world in which man lives, operated on ideal forms.

3. The spirituality as a subjective world of man exists as inner, private life of a person. It is given in the inner contemplation of man, is deployed in its immanent ideal space and time. Spirituality is entirely subjective, it represents "Me" of the person, acts as being and the peculiarity of this "Me". The spirituality is subjective-individual.

The spirituality, therefore, can be defined as the man's spiritual life; it is subjective-ideal world.

Relatively recently in the modern literature the concept of "spiritual production" is reveal. The spiritual production is the production of consciousness carried out by specialized groups of people professionally engaged by qualified mental labor. The results of their work are:

1) Ideas, theories, images, spiritual values;

2) Spiritual social ties of individuals;

3) Spirituality of the person.

The spiritual structure of production includes the scientific, aesthetic and religious kind of the reality understanding.

You need to pay attention to the fact that although politics, law, morality are forms of social consciousness, but they are not spiritual production. The fact that morality is not the result of creative activity of the ideologues. Ideologues, of course, engaged in the study of the ethical and moral spheres of life of society and man. But they didn't create any moral rule or principle: their creation is the result of centuries of development of human society, the transformation of any rational norms in the demand addressed by the society for each member, to the association of people could maintain their existence.

Politics and law also are not the kinds of cultural production, because created here social relations are not primarily spiritual. To explain this conclusion can be as follows: material or spiritual 
data communication is defined in terms of either material or ideal objects. So if, for example, the lawyer develops a system of relations to property, as a material object, then, consequently, the legal property relations are not spiritual, but material. Political relations are about power and power relations of domination and subordination is ultimately material relations.

Science, art, religion are engaged in the production of ideas, images, representations, so to speak, in "pure" form. In each of these forms of social consciousness reality is presented in a consistent and specific form.

The phrase "spiritual production" should not mislead us and cause the attempt to equate the spiritual with material production. Their differences are quite obvious. Different summary of production are material or spiritual objects. In the spiritual production the labour is individual, in material production is individual and collective. Finally, we should not forget that if the goal of life for many people, material wealth, than spiritual wealth is not valuable.

\section{References:}

1. Berdyaev NA (1991) Self-cognition. Moscow. pp. 236-237.

2. Gegel' GVF (1932) Sochinenija. Moscow. T.1. pp. 208.

3. Montesk'e S (2015) Izbrannye proizvedenija. pp. 417.

4. (2014) Konstitucija Respubliki Uzbekistan. Tashkent, «Uzbekistan». - 76 p.

5. (2003) Ideja nacional'noj nezavisimosti. Tashkent, «Uzbekistan».

6. Kant I (1966) Sochinenija: V 6 t. Moscow, T.5. pp. 211.

7. Karimov IA (1992) Uzbekistan: svoj put' nezavisimosti i progressa. - Tashkent, «Uzbekistan».
8. Karimov IA (1999) Uzbekistan, ustremljonnyj v XXI vek. - Tashkent, «Uzbekistan».

9. Karimov IA (1995) Rodina svjashhenna dlja kazhdogo. - Tashkent, Uzbekistan, - pp.172.

10. Karimov IA (2009) Juksak ma`navijat engilmas kuch. - Toshkent, «O`zbekiston», $176 \mathrm{p}$.

11. Norkulov SD (2015) Transformacija obshhestvennogo soznanija v uslovijah formirovanija grazhdanskogo obshhestva V Uzbekistane. Available: http://credonew.ru/?p=344 (Accessed: 20.04.2015). 